\title{
The Concept of A Marriage Agreement in the Compilation of Islamic Law
}

\author{
Haerunnisa Yunus ${ }^{*}$, Rusli Rusli ${ }^{2}$, Abidin Abidin ${ }^{3}$ \\ ${ }^{1}$ Islamic Family Law Department, Postgraduate, Institut Agama Islam Negeri Palu \\ 2 Islamic Family Law Department, Postgraduate, Institut Agama Islam Negeri Palu \\ ${ }^{3}$ Faculty of Islamic Economis and Business, Institut Agama Islam Negeri Palu
}

\begin{abstract}
The aim of this paper is to discusse the concept of a marriage agreement in the Compilation of Islamic Law. This study is literature review research with a qualitative methods. The data was gathered through content analysis and written material. Data analysis was analyzed using grounded theory approach and thematic building. The result of research shows basically, there is no difference between the Marriage Law and the Islamic Law Compilation regarding the marriage agreement. Second, the legal consequences of the marriage agreement made by each party husband and wife, are binding. Therefore, if a violation occurs, each party can take legal action
\end{abstract}

ARTICLE

INFORMATION

Keywords:

Marriage agreement, Islamic law, compilation 


\section{Introduction}

Marriage is one of the Shari'a which aims to create harmony in the family. A harmonious family becomes a medium for creating order in society. ${ }^{1}$ Therefore, this issue has become a concern of women's movements in the world. ${ }^{2}$

One of the elements in a marriage to create this harmony is the marriage agreement, which is carried out before marriage. In Islamic law, marriage agreement is neither obligatory nor prohibited by law. However, with the existence of a marriage agreement, the husband and wife relationship will feel safe because if one day their relationship turns out to be "cracked" and even leads to divorce, then there is something that can be used as a reference and legal basis.

A marriage agreement can also be used as a means to minimize the occurrence of a divorce. Because, if from the start an agreement has been made, then in the event of a divorce, each party feels burdened with the obligations in the agreement so that he will rethink filing for divorce, because divorce is also very undesirable in a household.

In making a marriage agreement, there are conditions that must be considered for its validity. Among these

1 Rusli Rusli, "The Role of Family in Preventing Social Conflict in Society From Islamic Perspectives," HUNAFA: Jurnal Studia Islamika 17, no. 1 (2020): 108-122.

2 Rusli Rusli, "An Analysis of Islamic Feminism in Indonesia: Reconstruction of Islamic Legal Issues on Gender Relations," Hunafa: Jurnal Studia Islamika 3, no. 1 (2006): 1-12, https://www.jurnalhunafa.org/index.php/huna fa/article/view/239.; See also Rusli Rusli, Islamic Feminism: Responses of Muslim Feminists to Gender Inequality in Indonesia (Palu: Irshed Press, 2006). are the marriage agreement must be written, and made before the marriage takes place. Since the marriage takes place, the agreement is attached to the marriage certificate and is an inseparable part of the marriage certificate, and is made with mutual consent, legalized by a civil registry employee, and may not contradict law, religion and morals. ${ }^{3}$

Law No. 1 of 1974 which was later amended by Law No. 16 of 2019 concerning marriage, does not specifically mention the things that can be agreed upon, except only stating that the agreement cannot be ratified if it violates legal and moral boundaries. This means that all matters as long as they are not against the law and morality can be stated in the agreement, for example regarding assets before and after marriage or divorce, child care, responsibility for household tasks, making bank accounts, family relationships, inheritance, prohibition of violence and pursuing education. 4,5 Confirmed in the Compilation of Islamic Law Article 47 (2). The agreement in

3 Maharani Kartika Puji Karisma, Akibat Hukum Perjanjan Kawin Yang Dibuat Setelah Perkawinan (Studi Kasus: Penetapan Pengadilan Negeri Nomor. 459/Pdt/P/2007/PN.Jkt.Tmr), 2013, 3.

4 Ru'ah Abdulla, Perjanjian Dalam Perkawinan Perspektif Hukum Islam Dan PerundangUndang, Institut Agama Islam Negeri Sultan Maulana Hasanuddin Banten, 3 (2013), 38.

${ }^{5}$ Sukaenah, S., Rusli, R., \& B, M. T. (2020). The Effectiveness of Indonesia Supreme Court Regulation Number 1 Year 2016 Concerning Mediation of Marriage Disputes INTERNATIONAL JOURNAL OF CONTEMPORARY ISLAMIC LAW AND SOCIETY, 2(1), 63-80. 
paragraph (1) can include a mixture of personal assets and separation of livelihood assets of each as long as it does not contradict Islamic law. ${ }^{6}$

In this article, it is stated that as long as it does not contradict Islamic law, a marriage agreement can include personal livelihood assets, separation of individual livelihood assets, determining their respective authority to enter into a mortgage bond (agreement with the bank, for example) on personal and collective assets.

As for the agreement in the third form, there are differences of opinion among the scholars. For example, his wife asked him not to do polygamous marriage with other women, a number of scholars including the Syafi'i scholars argued that these conditions could not be fulfilled, but did not cancel the marriage contract if it was done. Their reason is that this includes the conditions for forbidding something lawful as mentioned in the hadith of the Prophet above and also not included in what is regulated in the book of Allah. ${ }^{7}$

Everything that Allah commands in Islamic law must have purposes, including the agreement in marriage. Regarding the law on the agreement of one wife or husband, there were differences of opinion among the Muslim scholars, whether or not the agreement could affect the validity of the marriage.

There are a number of verses related to covenants, but there is not verse or hadith that explicitly explains the issue of a marriage agreement. It only

\footnotetext{
${ }^{6}$ Ibid., 39

7 Ibid., 8
}

states that it is permissible to make an agreement in any form as long as it does not prohibit what is lawful. However, what has been explained above can represent the whole. It can be understood that, in general, the basis of contract law is not only in the area of marriage, but covers all areas.

\section{Literature Review}

\subsection{Definition of Prenuptial Agreement}

Prenuptial Agreement is an agreement made before the marriage takes place and binds both parties to the bride and groom who are getting married. The pre-marriage agreement is valid from the time the marriage takes place and it regulates how the assets of the husband and wife will be divided in the event of a divorce, the death of one of the partners. This agreement can also contain how all family financial matters will be arranged during the marriage. ${ }^{8}$ In general, the marriage agreement contains the arrangement of the assets of the prospective husband and wife. Proceed with the aim of regulating the effects of marriage regarding wealth. ${ }^{9}$

Historically, this marriage agreement was made to protect the wife's property that was brought into the marriage. At that time, women in marriage were considered incompetent in managing all matters of their assets, so

8 Onny Medaline," Perjanjian Kawin Dalam Perspektif Hukum Nasional, Jurnal Ilmia Abadi Ilmu Vol. 3 (2010). 334

9 Ru'fah Abdullah, "Perjanjian dalam Perkawinan Perspektif Islam dan PerundangUndangan," Jurnal Studi Gender dan Anak, 3 (2016), 33.

e-ISSN: 2715-4580 p-ISSN: 2715-8268 
they had to get a husband as a companion.

Marriage agreement generally stipulates how their assets will be divided if there is a separation of the relationship between the two, whether due to divorce or death. It also contains matters relating to the future interests of their household. This is as stated in article 29 of Law No. 1 of 1974 on amendment No. 16 of 2019.10 However, marriage agreements are not only limited to financial or property issues, but there are other things that are also important to be agreed upon, for example regarding domestic violence, continuing education when married, and so on.

A marriage agreement is an example of a formal agreement, an agreement that not only requires an agreement, but also requires the stipulation of the agreement into a certain form of agreement or accompanied by certain formalities, in addition to fulfilling the validity of the agreement in general and must also be written in authentic certificate. ${ }^{11}$

\subsection{Forms of Marriage Agreement}

In Law No. 1 of 1974 as amended by Law no. 16 of 2019 concerning marriage, marriage agreement is stipulated in written form. Here, it is not required by a notarial deed, it is enough just to be signed by the husband and wife

10 Haedah Faradz, "Tujuan Dan Manfaat Perjanjian Perkawinan," Jurnal Dinamika Hukum, 8.3 (2008), 250.

11 Ibid., 251. who entered into the marriage agreement. ${ }^{12}$

In the Civil Code, it requires that the marriage agreement be made notarially, including amendments to it. If not, then the marriage agreement will be threatened with nullification by law. In Article 147 of the Civil Code, every marriage agreement must be made with a notary deed before the marriage takes place. Furthermore, in Article 148 of the Civil Code, it is stated that all changes in the marriage agreement cannot be carried out in any other way, but by deed and in the same form as the previous marriage agreement. ${ }^{13}$

Before the marriage takes place, the prospective husband and wife can still change the marriage agreement they made. However, the change must be made with a notarial deed, while the people who previously participated as parties in realizing the marriage agreement must be included again to avoid conflicts. ${ }^{14}$ When those people do not like it, change can be made. ${ }^{15}$

In a marriage agreement, the separation of marital assets, an association of profit and loss, and union of results and income, is regulated as follows: ${ }^{16}$

12 Erliyani, Rahmida ,23.

13 Ibid., 24

${ }^{14}$ Rusli, R. (2020). The Role of Family in Preventing Social Conflict in Society From Islamic Perspectives. Hunafa: Jurnal Studia Islamika, 17(1), 108-122.

15 R. Soetojo Prawirohamidjojo dan Asis Safioedin, " Akibat Hukum Perjanjian Perkawinan Yang Di buat Setelah Perkawinan Berlangsung, Jurnal Ilmu Hukum Vol. 3 (2015), 87.

16 Erliyani, Rahmida, 25.

e-ISSN: 2715-4580 p-ISSN: 2715-8268 
1. Separation of marital property

In Indonesia, in reality, the most commonly held marriage agreements are those that completely eliminate the association of assets. If before the marriage the husband and wife did not make a marriage agreement, then legally there was a unanimous agreement. This means that the legal effect of the assets brought by the husband and wife becomes one in the assets of the marriage. The two parties must state firmly that there is no association of assets and do not want the association of assets in other forms, for example union of profit and loss. ${ }^{17}$

According to Article 114 of the Civil Code, it is stated that "the absence of association of assets does not mean that there is no union of profit and loss, unless this is also expressly negated". ${ }^{18}$

If the agreement contains the separation of marital assets, then each party (husband and wife) remains the owner of the items they bring into the marriage. Likewise, with the absence of a profit and loss union, the assets obtained remain their respective property. Therefore, in the marriage, there are two assets, namely the husband's personal assets and the wife's personal assets. ${ }^{19}$

2. Incorporation of profit and loss

A marriage agreement with a union of profit and loss occurs if the

17 R. Soetojo Prawirohamidjojo dan Asis Safioedin, " Hukum Orang Dan Keluarga (Bandung: Alumni, 1986). 81.

18 Soesilo, 61.

19 Annisa Istrianty dan Erwan Priambada, "Akibat hukum perjanjian perkawinan yang dibuat setelah perkawinan berlangsung," Jurnal Privat Law, III.2 (2015), 87. prospective husband and wife expressly state that they want this kindof agreement in the certificate. This is regulated in Civil Code Article 155. ${ }^{20}$

With the union of a profit and loss, all the advantages and disadvantages obtained during the marriage will become the rights and responsibilities of the husband and wife together, as well as a part of their burden in an equal proportion. If the marriage agreement determines the existence of a profit-loss association, then assets in the form of movable property must be recorded in the marriage agreement deed. ${ }^{21}, 22$ The distribution of the mixture of profit and loss is usually carried out in two equal parts, unless the marriage agreement stipulates otherwise (Article 156 of the Civil Code). ${ }^{23}$

In order to prevent difficulties of proof in the future, unregistered objects must be clearly specified in the marriage agreement, or in a report signed by a husband and wife before a notary, and attached to the marriage agreement concerned (Article 165, Civil Law). ${ }^{24}$

3. Incorporation of income

20 Ibid., 7

${ }^{21}$ Erliyani, Rahmida, 25.

${ }^{22}$ Muslih, I., Nurdin, N., \& Marzuki, M. (2020). Effectiveness of Marriage Services Through Information System Management (SIMKAH) at Palu City Religious Court INTERNATIONAL JOURNAL OF CONTEMPORARY ISLAMIC LAW AND SOCIETY, 2(1), 20-36.

23 Soesilo, 61.

24 Ahmad Sainul, "Konsep Perjanjian Perkawinan Di Indonesia," Jurnal El-Qanuny, 4 (2018),7.

e-ISSN: 2715-4580

p-ISSN: 2715-8268 
Only one article that regulates this issue, namely Article 164 of the Civil Code, states as follows: "The agreement, between husband and wife will only apply to the incorporation of income, meaning that tacitly there is no incorporation of all assets according to law, and the absence of a profit and loss merge."

\subsection{The content of marriage agreement}

The object of the agreement is not regulated in Law No.1 of 1974. Both parties (husband and wife) are jointly free to determine the contents of the marriage agreement as long as the agreement does not violate the boundaries of religious law and morality. ${ }^{25}$ In Western law, it is stated that both parties (husband and wife) are free to determine the contents of the marriage agreement that they make. ${ }^{26}$

In Government Regulation Number 9 of 1975 concerning the implementation of Law No.1 of 1974, as long as this marriage agreement does not further regulate what restrictions can be agreed, whether regarding property or not, for example, it can be interpreted. This agreement can include the following: 27

1. The agreement on the incorporation personal assets;

2. The separation of their livelihood assets;

3. The agreement regarding the separation of joint assets or company assets that is made, and this may not

\footnotetext{
25 Erliyani, Rahmida, 28.

26 Safioedin, 78"

27 Ibid., 80
}

eliminate the husband's obligation to meet household needs;

4. The agreement for mixing and separating personal assets for their respective livelihoods stipulates the respective authorities to enter into mortgage ties on personal assets and joint assets or company assets.

As a result, the marriage agreement regarding such assets is binding on both husband and wife and third parties, and can only be revoked with the joint agreement of the husband and wife, and must register at the Office of the Registrar of Marriages where the marriage takes place.

\section{Methodology}

This research is a library research, ${ }^{28}, 29$ to understand the general view of jurists in answering the issue of marriage agreements and also their relation to the Compilation of Islamic Laws and the applicable marriage laws in Indonesia. Because of that, the data studied were books, journals, magazines, manuscripts, all of which were sourced from literature related to the issue of marriage contract.

The approach in this study used a normative and juridical approach, whether it comes from the legal basis of the Quran and Hadith, as well as the principles of fiqh and ushul figh, with explanations of the opinions of the scholars of Islamic law relating to the

${ }^{28}$ Muhammas Nazir, Metode Penelitian, (Bogor: Ghalia Indonesia, 1988), 54

${ }^{29}$ Salam, K., \& Nurdin, N. (2015). AlMishbah: Jurnal Ilmu Dakwah dan Komunikasi. Al-Mishbah: Jurnal Ilmu Dakwah dan Komunikasi, 11(1), 47-64.

e-ISSN: $2715-4580$ p-ISSN: 2715-8268 
problems under study so that they can understand the legal objectives deeply. ${ }^{30}$

\section{Result and Discussion}

\subsection{The Concept of Marital Agreement in Indonesia Mariage Law}

So far, only a small proportion of Indonesian people have entered into marriage agreements. There are opinions that making marriage agreements for prospective husband and wife seems very inappropriate and in contrary to Eastern customs and traditions. The assumption that after marriage everything melts into one makes each of their partners reluctant to make the marriage agreement. In fact, the marriage agreement does not only contain matters of property, but also the division of roles and child care.

The marriage agreement itself is a form of legal action called "agreement". Legal experts define an agreement as an event where one person promises another person to carry out something. ${ }^{31}$

According to the Marriage Law and the Compilation of Islamic Law, an agreement is a collective agreement for a prospective husband and wife that must be fulfilled when they are married. However, if one of them violates, then either can sue to ask for the annulment of the marriage, and vice versa, as a

${ }^{30}$ Iqbal, M., Rusli, R., \& Musyahidah, M. (2019). Management Strategies of Professional Zakat Funds for Mustahiq Family Welfare By Amil Zakat Body INTERNATIONAL JOURNAL OF CONTEMPORARY ISLAMIC LAW AND SOCIETY, 1(1), 39-51.

31 Ibid., 30 sanction for not fulfilling the marriage agreement. This agreement can also be referred to as a pre-marriage agreement because the agreement is carried out at the time or before the marriage takes place, and must be legalized by the Marriage Registration Officer (KHI, Article $47 \mathrm{KHI}$ and Marriage Law, article 29, paragraph 1). Marriage agreement cannot be ratified, if it violates legal, religious and moral boundaries (Marriage Law, Article 29 paragraph 2). ${ }^{32}$

The marriage agreement in Indonesia is regulated in Marriage Law and Compilation of Islamic Law. This is so necessary that the marriage agreement runs within the corridor of law, and to guarantee their rights in agreement.

1. Marriage Agreement in Marriage Law Number 1 Year 1974

In general, marriage agreement contains arrangements for the assets of the prospective husband and wife, and is legalized by a marriage registrar. ${ }^{33}$ This term is taken from Chapter V of Marriage Law No. 1 Year 1974. Meanwhile, regarding the meaning of this marriage agreement, no explanation is obtained, it only regulates the time of making, validity, time of enforcement, and amendment of the agreement. So, it does not regulate the contents of the agreement at all. ${ }^{34}$

32 Khaeron Sirin, " Perkawinan Mazhab Indonesia: Pergulatan Antara Negara, Agama dan Perempuan, 2018, 98.

33 Hanafi Arief, "Implementasi Yuridis Perjanjian Kawin dalam Sistem Hukum Positif di Indonesia," Jurnal Ilmu Hukum, 15 (2015), 150.

${ }^{34}$ Ibid., 149 
Commenting on Article 29 of the Marriage Law, K. Wantjik Saleh said: "Whereas the scope of the marriage agreement does not specify what the agreement is, for example regarding property. Since there is no such restriction, it can be concluded that the agreement is very broad, that include various things. In the elucidation of the article, it can only be said that what is meant by 'agreement' does not include ta'lik talak." 35

Since the marriage agreement is the basis for the management of assets in marriage, this arrangement of marriage agreement should be put after the regulation of the rights and obligations of husband and wife and the regulation of assets in marriage. With regard to the substance of the marriage agreement, Article 29 of Marriage Law No. 1 Year1974 does not explicitly stipulate that the marriage agreement is only limited to marital assets, so implicitly it can be interpreted that the marriage agreement is not limited to only regulating marital assets. ${ }^{36}$

\subsection{Legal consequences of marriage agreement}

The marriage agreement is a means of protecting the assets of the husband and wife. Certaintly, a marriage agreement leads to legal consequences that include: ${ }^{37}$

35 Sukardi, "Kajian Yuridis Perjanjian Perkawinan Menurut Kitab Undang-Undang Hukum Perdata, Undang-Undang Nomor 1 Tahun 1974 dan Kompilasi Hukum Islam, Jurnal Katulistiwa, Vol 6 No. 1 2016, 30"

36 Sirin, 99.

37 Masriani, 57. a. By law, the parties must carry out their obligations and rights. If a violation occurs, they must be prepared to accept the legal consequence.

b. Psychologically, the marriage agreement will cause a feeling of distrust towards the termination of his life. This will result in unhappiness in running the household.

c. Sociologically and culturally, the marriage agreement creates a culture shock. Eastern society certainly rejects the existence of a marriage agreement, because it considers it to be something that only emphasizes property, although the marriage agreement is not always oriented to the assets in marriage.

Marriage agreements are made with the aim of providing legal protection for parties in good faith from other parties who are not in good faith. If at another time problems arise between the parties, the marriage agreement can become the basis for each party, namely husband and wife, to take legal action.

Especially for agreements in the form of assets, the legal status is binding on the parties, including third parties, since the marriage is taking place. If the parties intend to revoke the asset agreement, they must register it at the Office of Marriage Affairs, where the marriage will take place. The revocation of the marriage agreement after being registered is automatically binding on the husband and wife, but not to a third party, it must first be published in a newspaper within a maximum period of 
six months. ${ }^{38}$ If they violate the agreement they have made, then they can file a lawsuit at the Religious Court.

Finally, it is explained in Marriage Law, Article 52, especially for husbands who are polygamous, they may enter into marriage agreements with their wives, regarding their place of residence, turnaround times, and household expenses. This correspondsto Hendry Lee A Weng's opinion that a marriage agreement is not only in the form of assets. However, it is permissible to make a marriage agreement in other forms. Thus it is clear, the object of the marriage agreement is not only in the form of property, but also is allowed in other forms, as long as the agreement does not violate morality and Islamic teachings. ${ }^{39}$

\section{Conclusions}

From the above discussion, it can be concluded. First, basically, there is no difference between the Marriage Law and the Islamic Law Compilation regarding the marriage agreement. Second, the legal consequences of the marriage agreement made by each party-husband and wife, are binding. Therefore, if a violation occurs, each party can take legal action.

\section{REFERENCES}

$\begin{array}{rrr}\text { Abdillah, Yasin } & \text { Yusuf, } & \text { "Perjanjian } \\ \text { Perkawinan } & \text { Sebagai } & \text { Upaya } \\ \text { Membentuk Keluarga } & \text { Bahagia } \\ \text { (Tinjauan Maqasid asy- Syariah)," }\end{array}$

38 Sainul, 36.

39 Ibid., 69
Jurnal Al-ahwal, 10 (2017).

Abdulkadir, Muhammad, Hukum dan Penelitian Hukum (Bandung: Citra Aditya Bakti, 2004).

Abdullah, Ru'ah, Perjanjian Dalam Perkawinan Perspektif Hukum Islam dan Perundang-Undang, Institut Agama Islam Negeri Sultan Maulana Hasanuddin Banten, 3 (2013).

Abdurrahman, Kompilasi Hukum Islam Di Indonesia (Jakarta: Akademika Presindo, 1995).

Adang, Yesmil Anawar dan, Pengantar Sosisologi Hukum (Jakarta: Drasindo, 2008).

Ahmad Royani, PerjanjianKawin Yang Dibuat Setelah Perkawinan Terhadap Pihak Ketiga (Pasca Putusan Mahkama Konstitutsi Nomor 69/PUU-XIII/2015), 5,6

Albar, Ahmad Dahlan dan Firdaus, Perjanjian pranikah solusi bagi wanita, 3 (2016).

Ansori, Abdul Ghafur, Hukum Perjanjian Islam Di Indonesia: Konsep, Regulasi, dan Implementasi, (Jogjakarta: Gajah Mada Univesity Press, 2018).

Arief, Hanafi, "Implementasi Yuridis Perjanjian Kawin dalam Sistem Hukum Positif di Indonesia," Jurnal Ilmu Hukum, 15 (2015).

Asikin, Amiruddin dan Zainal, Pengantar Metode Penelitian Hukum (Jakarta: Rajawali Pres, 2012)

Asmin, Perkawinan Antar Agama Di Tinjau Dari Undang-Undang Perkawinan No 1/1974 (Jakarta: Dian Rakyat, 1986).

Azrianti, Seftia, "Analisa Yuridis PerjanjianPerkawinan Dan Akibat Hukum Bagi Para Pihak Berdasarkan Kompilasi Hukum e-ISSN: 2715-4580 p-ISSN: 2715-8268 
Islam Dan Undang-Undang Nomor 1 Tahun 1974 Tentang Perkawinan," Jurnal Petita, 1.2 (2014).

Azzmi, Takwim, "Analisis Perjanjian Perkawinan Dan Akibat Hukumnya Ditinjau," Jurnal Ilmiah Ilmu Hukum QISTIE, 12.1 (2019).

Budiawan, Afiq, "Moderisasi Hukum Keluarga Di Indonesia: Studi Terhadap Diskursus dan Legislasi Perjanjian Perkawinan Islam Indonesia Oleh: Afiq Budiawan," Jurnal Madania, 7 (2017).

Burhanudin, Achmad Asfi, "Konsep Perjanjian Perkawinan dalam Perspektif Perbandingan Hukum ( Hukum Perdata dan Hukum Islam )," Jurnal El-Faqih, 5 (2019).

Darminto, Dwi Prastowo, Pengertian Analisis Menurut Para Ahli, 2018.

Dewi, Haruri Sinar, "Efektifitas Putusan MK Nomor 69/puu-vii/2015 Studi Kasus Dari Putusan MK Nomor 69/PUU- VIII/2015 Terhadap Pembuatan Akta Perjanjian Kawin Bagi Pihak Ketiga," Jurnal Hukum, 2.69 (2018).

Elly. M. Setiadi, Usman Koli, Pengantar Sosiologi (pemahaman fakta dan gejala permasalahan sosial: Teori, Aplikasi, Dan Pemecahannya (Jakarta: Prenada Media Group, 2011).

Erliyani, Rahmida, fatmah surah, Aspek Hukum Perjanjian Perkawinan, ed. oleh K-Media, Aspek Hukum Perjanjian Perkawinan (Jogjakarta, 2016).

Eva, dan Dwinopianti, Implikasi dan Akibat Hukum Putusan Mahkama Konstitusi Nomor 69/PUUᄀ-XII/2015 Terhadap Pembuataan Akta Perjanjian Perkawinan Setelah Kawin Yang Dibuat
Di hadapan Notaris, 2017.

Faradz, Haedah, "Tujuan Dan Manfaat

Perjanjian Perkawinan," Jurnal

Dinamika Hukum, 8.3 (2008).

Filma Tamengkel, Dampak Yuridis Perjanjian Pra Nikah (Prenuptial Agreement)Di tinjau Dari UndangUndang Nomor 1 Tahun 1974 Tentang Perkawinan, 3 (2015).

Ghozali, Abdul Rahman, Fiqih Munakahat (Jakarta: Kencana, 2015). Habibah, St., Analisis Hukum Islam Tentang Pelanggaran Perjanjian Perkawinan, (Al-Bayyinah: Jurnal of Islamic Law, VI, 1979.

Hamdani, H.S.A., Risalah Nikah (Hukum Perkawinan Islam) (Jakarta: Pustaka Amani, 2002).

Hamzah, Andi, Kamus Hukum, 1986.

Haris, Syafuddin, Kedudukan Taklik Talak

Dalam Perkawinan Islam Ditinjau Dari Hukum Perjanjian Perkawinan, 8 (2013).

Hartati, Ismail Nurdin dan sri, Metode Penelitian Sosial (Surabaya: Media

Sahabat Cendekia, 2019).

Hosen, Ibrohim, Figh Perbandingan dalam Masalah Nikah dan Rujuk (Jakarta: Ihya Ulumuddin, 1971).

Iqbal, M., Rusli, R., \& Musyahidah, M. (2019). Management Strategies of Professional Zakat Funds for Mustahiq Family Welfare By Amil Zakat Body INTERNATIONAL JOURNAL OF CONTEMPORARY ISLAMIC LAW AND SOCIETY, 1(1), 39-51.

Karisma, Maharani Kartika Puji,

“Dinamika Batasan Kebebasan

Membuat Perjanjian Kawin Dalam

Asas Kebebasan Berkontrak," 2019.

Kompilasi Hukum Islam, Kompilasi Hukum

e-ISSN: 2715-4580

p-ISSN: 2715-8268 
International Journal of Contemporary Islamic Law and Society

Vol. 2 No. 2 Tahun 2020

Islam

Lubis, M. Solly, Filsafat Ilmu dan Penelitian (Bandung: Mandar Maju, 2007).

Madiong, Baso, Sosilogi Hukum (Suatu Pengantar (Makassar: Sah Media Makassar, 2014).

Mamudji, Soerjono Soekanto dan Sri, Penelitian Hukum Normatif Suatu Tinjauan Singkat (Jakarta: Rajawali Grafindo, 2003).

Manan, Abdul, Aneka Masalah Hukum Perdata Islam (Jakarta: Kencana, 2017).

Marzuki, Peter Mahmud, Pengantar Ilmu Hukum (Jakarta: Kencana Prenada Media Group, 2008).

Masriani, Yulies Tiena, Perjanjian Perkawinan Dalam Pandangan Hukum Islam.

Medaline, Onny, "Perjanjian kawin dalam persfektif hukum nasional," Perjanjian Kawin Dalam Perspektif Hukum Nasional, 3 (2010).

Moch Chidir Ali, H. Achmad Samsudin dan Mashudi, Pengertian-Pengertian Elementer Hukum Perjanjian Perdata (Bandung: Mandar Maju, 1993).

Muliadi, Herry, Analisis Hukum Terhadap Perjanjian Perkawinan, 2014.

Muslih, I., Nurdin, N., \& Marzuki, M. (2020). Effectiveness of Marriage Services Through Information System Management (SIMKAH) at Palu City Religious Court INTERNATIONAL JOURNAL OF CONTEMPORARY ISLAMIC LAW AND SOCIETY, 2(1), 20-36.

Ningsih, Natal ia, I Made Arya Utama, I Made Sarjana, "Kekuatan mengikat akta notaris perjanjian perkawinan terkait harta bersama yang dibuat pasca pencatatan perkawinan," Jurnal hukum kenotariatan, 2.2017 (2017).

Pakaya, Susisusanti G., "Perlindungan Hukum Terhadap Harta Bawaan Dengan Akta Perjanjian Perkawinan," jurnal ilmu hukum legal opinion, 4.2 (2016).

Pandi, Intan, "Akibat Hukum Perjanjian Perkawinan yang Di buat Dihadapan Notaris Terhadap Kreditur Sebagai Pihak Ketiga, 2018.

Paramitra, Erdhyan, "Akibat Hukum Perjanjian Perkawinan Yang Tidak Di sahkan Oleh Pegawai Pencatat Perkawinan," Program Magister Kenotariatan Fakultas Hukum Universitas Sebelah Maret Surakarta, (2017).

Priambada, Annisa Istrianty dan Erwan, "Akibat hukum perjanjian perkawinan yang dibuat setelah perkawinan berlangsung," Jurnal Privat Law, III.2 (2015)

Primbada, Annisa Istrianty dan Erwan, Akibat Hukum Perjanjian Perkawinan Yang Dibuat setelah perkawinan berlangsung, 3 (2015).

Rafiq, Ahmad, Hukum Perdata Islam di Indonesia (Jakarta: Rajagrafindo Persada, 2013).

Rismadewi, Avina, Anak Agung, Sri Utari, Bagian Hukum, Bisnis Fakultas, dan Hukum Universitas, "Kekuatan hukum dari sebuah akta di bawah tangan," Jurnal Hukum, 2 (2016).

Roring, febria vivinianti cathy, "perlindungan hukum terhadap harta dalam perjanjian perkawinan," Lex Privatum, 2.2 (2014). 
Rusli, R. (2020). The Role of Family in Preventing Social Conflict in Society From Islamic Perspectives. Hunafa: Jurnal Studia Islamika, 17(1), 108-122.

Rusli, Rusli, "An Analysis of Islamic Feminism in Indonesia: Reconstruction of Islamic Legal Issues on Gender Relations" Hunafa: Jurnal Studia Islamika 3, no. 1 (2006): 1-12.

Rusli, Rusli,Islamic Feminism: Responses of Muslim Feministsto GenderInequality in Indonesia. Palu: Irshed Press, 2006.

Rusli, Rusli, "The Role of Family in Preventing Social Conflict in Society From Islamic Perspectives," Hunafa: Jurnal Studia Islamika 17, no. 1 (2020): 108-122.

Safioedin, R. Soetojo Prawirohamidjojo dan Asis, Akibat Hukum Perjanjian Perkawinan Yang Di buat Setelah Perkawinan Berlangsung, 3 (2015).

Sainul, Ahmad, "Konsep Perjanjian Perkawinan Di Indonesia," Jurnal ElQanuny, 4 (2018).

Salam, K., \& Nurdin, N. (2015). AlMishbah: Jurnal Ilmu Dakwah dan Komunikasi. Al-Mishbah: Jurnal Ilmu Dakwah dan Komunikasi, 11(1), 47-64.

Salim HS, Erlies Septiana Nurban, Penerapan Teori Hukum Pada Penelitian Tesis dan Disertasi (Jakarta: Rajawali Pres, 2016).

Sanjaya, Ida, "Kedudukan Perjanjian Perkawinan Yang Tidak Tercatat Di Catatan Sipil Apabila Terjadi Perceraian," Jurnal Hukum Bisnis, 2 (2018).

Satriawan, Hera Alvian, Pengaturan Perjanjian Perkawinan Bedasarkan Peraturan Menteri Agama Nomor 19
Tahun 2018 Tentang Pencatat Perkawina, 1 (2018).

Satriawan, Hera Alvina, "Pengaturan Perjanjian Perkawinan Berdasarkan Peraturan Menteri Agama Nomor 19 Tahun 2018 Tentang Pencatatan Perkawinan," Jurnal Unizar Law Review, 1.2 (2018).

Sirin, Khaeron, Perkawinan Mazhab Indonesia: Pergulatan Antara Negara, Agama dan Perempuan, 2018.

Soemiati, Hukum Perkawinan Islam dan Undang-Undang Perkawinan (Jogjakarta: Liberty, 1999)

Soesilo, Kitab Undang-Undang Hukum Perdata Burgerlijk Wetboek/BW.

Sonny Dewi Judiasih, Devinana Yuanitasari, dan Revi Inayatillah, "Model Perjanjian Kawin Yang Dibuat Setelah Perkawinan Berlangsung Pasca Berlakunya Putusan Mahkama Konstitusi Nomor 69/PUU-XIL/2015, 47 (2018).

Suardita, Claudia Verena Maudy Sridana dan I Ketut, " Akibat Hukum Terhadap Perjanjian Perkawinan Yang Tidak Didaftark

Subekti, Trusto, "Sahnya Perkawinan Menurut Undang-Undang Nomor 1 Tahun 1974 Tentang Perkawinan Ditinjau Dari Hukum Perjanjian," Jurnal Dinamika Hukum, 10.3 (2010).

Subendi, Hendi, Fiqih Muamalah (Jakarta: PT. Raja Grafindo Persada, 2007).

Subki, Ali Yusuf As-, fiqih Keluarga (Jakarta: Amzah, 2010).

Sudarso, Kamus Hukum, 2007.

Sugiono, Metode penelitian pendidikan pendekatan kuantitatif, kualitatif dan REd (Bandung: Alfabeta, 2012).

Suharizal, Intan Pandini Azmi Fendri dan, Akibat Hukum Perjanjian e-ISSN: 2715-4580 p-ISSN: 2715-8268 
Perkawinan Yang Dibuat Dihadapan Notaris Terhadap Kreditur Sebagai Pihak Ketiga.

Suharnoko, Hukum Perjanjian, Teori dan Analisis Kasus (Jakarta: Kencana, 2009).

Sukaenah, S., Rusli, R., \& B, M. T. (2020). The Effectiveness of Indonesia Supreme Court Regulation Number 1 Year 2016 Concerning Mediation of Marriage Disputes INTERNATIONAL JOURNAL OF CONTEMPORARY ISLAMIC LAW AND SOCIETY, 2(1), 63-80.

Sukardi, "Kajian Yuridis Perjanjian Perkawinan Menurut Kitab UndangUndang Hukum Perdata, UndangUndang Nomor 1 Tahun 1974 dan Kompilasi Hukum Islam," Jurnal Khatulistiwa, 6 (2016).

Sulistyowati, Herwin, Tinjauan Perjanjian Perkawinan Dalam Pandangan Hukum Nasional Dan Budaya Masyarakat.

Susanti, Dyah Ochtoriana, Perjanjian Kawin Sebagai Bentuk Perlindungan Hukum Bagi Pasangan Suami Istri Perspektif Maqadid Syariah, 1 (2015).

Susanti, Dyah Ochtorina, "Perjanjan Kawin Sebagai Bentuk Perlindungan Hukum Bagi Pasangan Suami Istri (Perspektif Maqashid Syariah)," Ulul Albab: Jurnal Studi dan Penelitian Hukum Islam, 1.2 (2018).

Sutinah, Bagong Suyanto dan, Metode Penelitian Sosial. Berbagai Pendekatan Alternatif, (Jakarta: Kencana, 2005).

Syahrizal, Darda, Kasus-Kasus Hukum Perdata Di Indonesia (Surabaya: pustaka gratama, 2011),

Syari'fah, Nadya Khanna, Tesis Perjanjian Pra Nikah Di Indonesia Perspektif Maqasid Syariah Jasser Auda, 2019.
Tarigan, Amiur Nuruddin dan Azhari Akmal, Hukum Perdata Islam Di Indonesia (Studi Kritis Perkembangan Hukum Islam dari Fikih, UU No. 1/1974 sampai KHI, 1 (2016).

Trusto Subekti, Sahnya Perkawinan Menurut Undang-Undang Nomor 1 Tahun 1974 Tentang Perkawina Ditinjau Dari Hukum Perjanjian, 10 (2010).

Undang-Undang Perkawinan No.1 Tahun 1974, Undang-Undang Perkawinan No.1 Tahun 1974

Viswandro, Kamus Istilah Hukum Sumber Rujukan Peristilaan Hukum, 2014.

Wafa, Moh. Ali, Hukum Perkawinan Di Indonesia Sebuah Kajian Dalam Hukum Islam Dan Hukum Materil (Tanggerang Selatan: Yayasan AsySyari'ah Moderen Indonesia, 2018).

wage lisa, nurdiyanawati, hamidah siti, "Batasan Perjanjian Perkawinan Yang Tidak Melanggar Hukum, Agama dan Kesusilaan," Jurnal imiah pendidikan pancasila dan kewarganegaraan, 4 (2019).

Yuli Pratiwi, Perjanjian Kawin dan Akibat Hukumnya Ditinjau Dari Hukum Islam dan Undang-Undang Perkawinan, 2011.

Yuvens, Damian Agata, Analisiskritis Terhadap Perjanjian Perkawinan Dalam Putusan Mahkama Konstitusi Nomor 69/PUU-XIII/2015, 14.

Zed, Mestika, Metode Penelitian Kepustakaan (Jakarta: Yayasan Obar Indonesia, 2004). 